\title{
Architektura i geneza ilów w górnym poziomie węgli brunatnych formacji poznańskiej ('środkowy miocen) - odkrywka Tomisławice k. Konina w środkowej Polsce
}

\author{
Lilianna Chomiak ${ }^{1}$, Pawel Urbański ${ }^{2}$, Marek Widera ${ }^{1}$
}

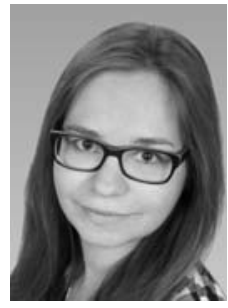

L. Chomniak

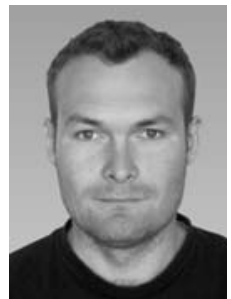

P. Urbański

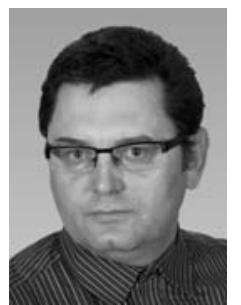

M. Widera

Architecture and origin of clays within the upper part of lignites of the Poznań Formation (Middle Miocene) - the Tomisławice lignite opencast mine near Konin, central Poland. Prz. Geol., 68: 526-534; doi: 10.7306./2020.19

A b s t r a c t. In the Tomistawice opencast mine, owned by the Konin Lignite Mine, a relatively widespread $\left(>1.5 \mathrm{~km}^{2}\right.$ ) and thick (up to $80 \mathrm{~cm}$ ) layer of clay occurs within the first mid-Polish lignite seam. These fine-grained sediments are interpreted as deposited in a long-lasting lake that existed in the mid-Miocene backswamp area. Due to the exploitation of this seam for electricity production, interbeddings of clastic sediments significantly reduce the quality of lignite. Currently, lignite is mined together with the clays in the Tomistawice opencast mine. Such procedure in extreme cases, where the maximum. thickness of the clay layer is up to 80 $\mathrm{cm}$, increases/may increase the ash content of the entire lignite seam almost twice. Therefore, selective lignite mining would be recommended, i.e. without clays, which unfortunately is not practiced due to technological and financial reasons.

Keywords: clastic sediments, palaeolake, first mid-Polish lignite seam, ash content, Miocene of Poland

W Polsce z węgla brunatnego wciąż produkuje się ok. 30-35\% energii elektrycznej (Kasztelewicz i in., 2018). Jest on wydobywany przez pięć kopalń, w dziewięciu odkrywkach, w tym w trzech należących do PątnówAdamów-Konin Kopalnia Węgla Brunatnego Konin Spółka Akcyjna (PAK KWB Konin S.A.) (Mazurek, Tymiński, 2019). Jedną z nich, a jednocześnie najmłodszą, jest odkrywka Tomisławice, gdzie eksploatację węgla rozpoczęto w 2011 r. (ryc. 1).

Obszar złoża Tomisławice, oprócz występowania środkowomioceńskiego pokładu węgla brunatnego, jest także bardzo interesujący pod względem poznawczym. W wyniku robót górniczych w latach 2015-2017 w pokładzie węglowym zostały odkryte osady piaszczyste o względnie dużej miąższości (do 1,8 m) i rozprzestrzenieniu lateralnym (300$500 \mathrm{~m}$ ). Było to pierwsze w Polsce odsłonięcie w obrębie miocenu węglonośnego osadów stożka (glifu) krewasowego (Widera, 2016a; Widera i in., 2017; Chomiak, 2020a). Ponadto w ich stropie udokumentowano unikatową dla formacji węglonośnych brekcję sedymentacyjną, która powstała najprawdopodobniej w wyniku spływu kohezyjnego laminowanych osadów wałów brzegowych mioceńskiej rzeki na jej obszar pozakorytowy, tj. na torfowisko (Widera, 2017).

W tym samym czasie (2015-2017) w tzw. górnej ławie pokładu węglowego stwierdzono występowanie cienkich warstw (do $20 \mathrm{~cm}$ ) iłów i pyłów węglistych (Widera i in., 2017). Dopiero w następnych latach, tj. 2018-2019, wraz $\mathrm{z}$ postępem robót górniczych, w tym zmiany kierunku eksploatacji z SSE-NNW na NNE-SSW, w pokładzie węgla brunatnego zostały odsłonięte wspomniane osady ilasto-pylaste w trzech wymiarach. Tworzyły one ciagła warstwę na długości co najmniej kilkuset metrów, a ich grubość sięgała kilkudziesięciu centymetrów.

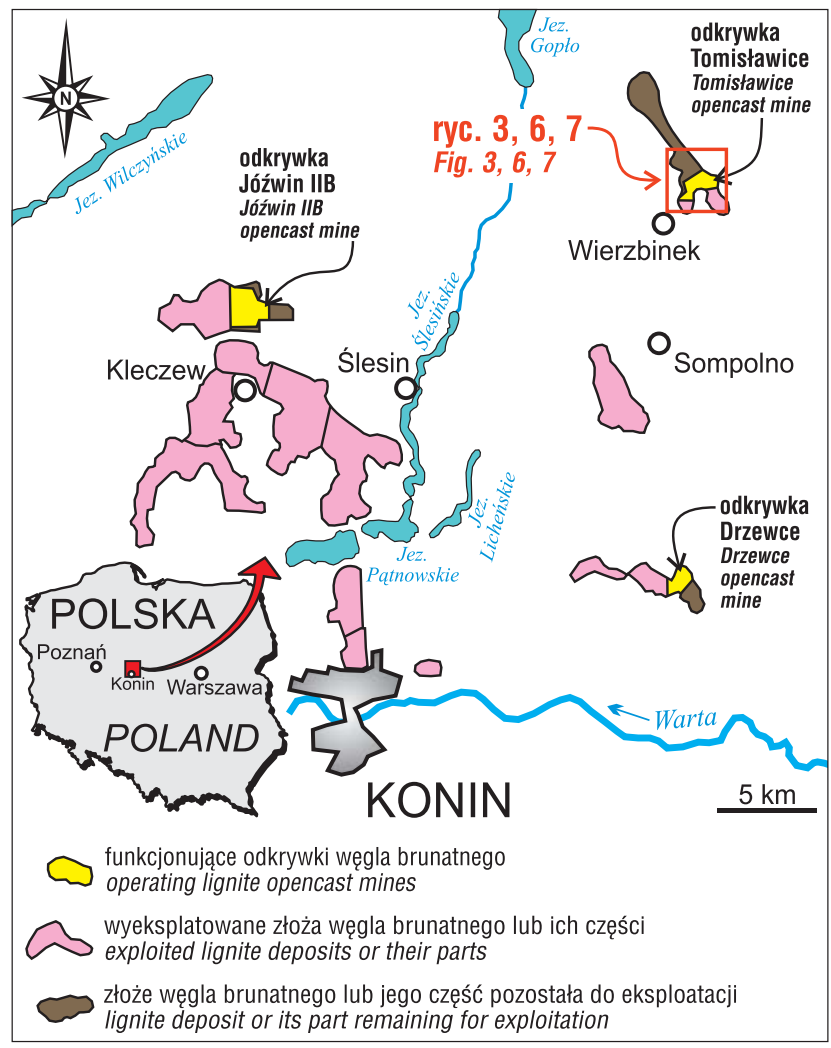

Ryc. 1. Mapa lokalizacyjna obszaru badań na tle środkowomioceńskich złóż węgla brunatnego i odkrywek w rejonie konińskim (wg Widery i in., 2017; Chomiak, 2020a, zmienione) Fig. 1. Location map of the study area against the background of lignite deposits and opencast mines in the Konin region (after Widera et al., 2017; Chomiak, 2020a, modified)

\footnotetext{
${ }^{1}$ Instytut Geologii UAM, ul. B. Krygowskiego 12, 61-680 Poznań; lilcho@amu.edu.pl; widera@amu.edu.pl

2 Państwowy Instytut Geologiczny - Państwowy Instytut Badawczy, ul. Rakowiecka 4, 00-975 Warszawa; pawel.urbanski@pgi.gov.pl
} 
Przewarstwienia tak drobnoklastycznych osadów, w dokumentacji geologicznej zwanych iłami (Kozula, 1999), są znane z wielu obszarów węglonośnych różnego wieku zarówno z zagranicznych (np. Horne i in., 1978; McCabe, 1984; Diessel i in., 2000; Lv i in., 2016; Erkoyun i in., 2017; Matys Grygar i in., 2017), jak i z polskich złóż węgla kamiennego i brunatnego (np. Kasiński, 1986, 1989; Mastalerz, 1992; Doktor, 2007; Widera, 2016a; Widera i in., 2017; Chomiak, 2020a). Ich depozycję można obserwować także w niewielkich zbiornikach wodnych na pozakorytowych torfowiskach współczesnych rzek (np. Gradziński i in., 2000; Morozova, Smith, 2000; Bos i in., 2009).

Podstawowym celem badań jest wykartowanie zasięgu warstwy iłów w obrębie pokładu węglowego odsłaniających się w odkrywce Tomisławice oraz ich charakterystyka miąższościowo-litologiczna. Takie podejście badawcze umożliwia poznanie architektury stratygraficznej i genezy wspomnianej warstwy osadów drobnoklastycznych. Zostanie także przedyskutowany wpływ iłów poddanych badaniom na popielność całego eksploatowanego dla celów energetycznych pokładu węgla brunatnego.

\section{SZKIC GEOLOGICZNY}

Obszar złoża węgla brunatnego Tomisławice znajduje się we wschodniej części niecki mogileńsko-łódzkiej, nad północno-wschodnim skłonem struktury solnej zwanej antykliną Gopła (Dadlez i in., 2000). Według podziału tektonicznego Polski teren objęty badaniami jest zlokalizowany w synklinorium szczecińsko-miechowskim, a dokładniej we wschodniej części segmentu mogileńsko-łódzkiego (Żelaźniewicz i in., 2011).

Strop mezozoiku na omawianym obszarze jest zbudowany głównie z późnokredowych margli (ryc. 2; Dadlez i in., 2000). Profil kenozoiku rozpoczynają ilaste zwietrzeliny skał kredowych, które lokalnie wypełniają depresje tektoniczne występujące $\mathrm{w}$ stropie mezozoiku. Na nich zalegają piaski glaukonitowe o zielonym odcieniu, powstałe w strefie nerytycznej wczesnooligoceńskiego morza epikontynentalnego (ryc. 2; Widera, Kita, 2007; Widera i in., 2017).

Na obszarze złoża Tomisławice neogen rozpoczyna się ciągłą warstwą piasków o miąższości do $20 \mathrm{~m}$, często wzbogaconych w substancję organiczną. Osady te należą do formacji koźmińskiej, powstałej we wczesnym/środkowym miocenie (ryc. 2). Neogen w tej części Polski kończą zalegające wyżej osady formacji poznańskiej, obejmującej przedział czasowy od środkowego miocenu po wczesny pliocen. Formacja poznańska tradycyjnie dzieli się na dwa ogniwa - starsze iłów szarych (ogniwo środkowopolskie) i młodsze wielkopolskie (ryc. 2; Piwocki, Ziembińska-Tworzydło, 1997; Widera, 2007).

Ogniwo iłów szarych składa się z pierwszego środkowopolskiego pokładu węgla brunatnego, którego miąższość na obszarze złoża Tomisławice wynosi średnio 6,9 m (Kozula, 2001). Ponadto do tego ogniwa należą tzw. iły szare, zalegające lokalnie w stropie ww. pokładu węglowego. Natomiast ogniwo wielkopolskie jest zbudowane głównie z iłów poznańskich (iły zielone i iły płomieniste). Jednakże ze względu na erozję i egzarację plejstoceńską występują one w formie reliktowej (Widera i in., 2017; Chomiak, 2020a).

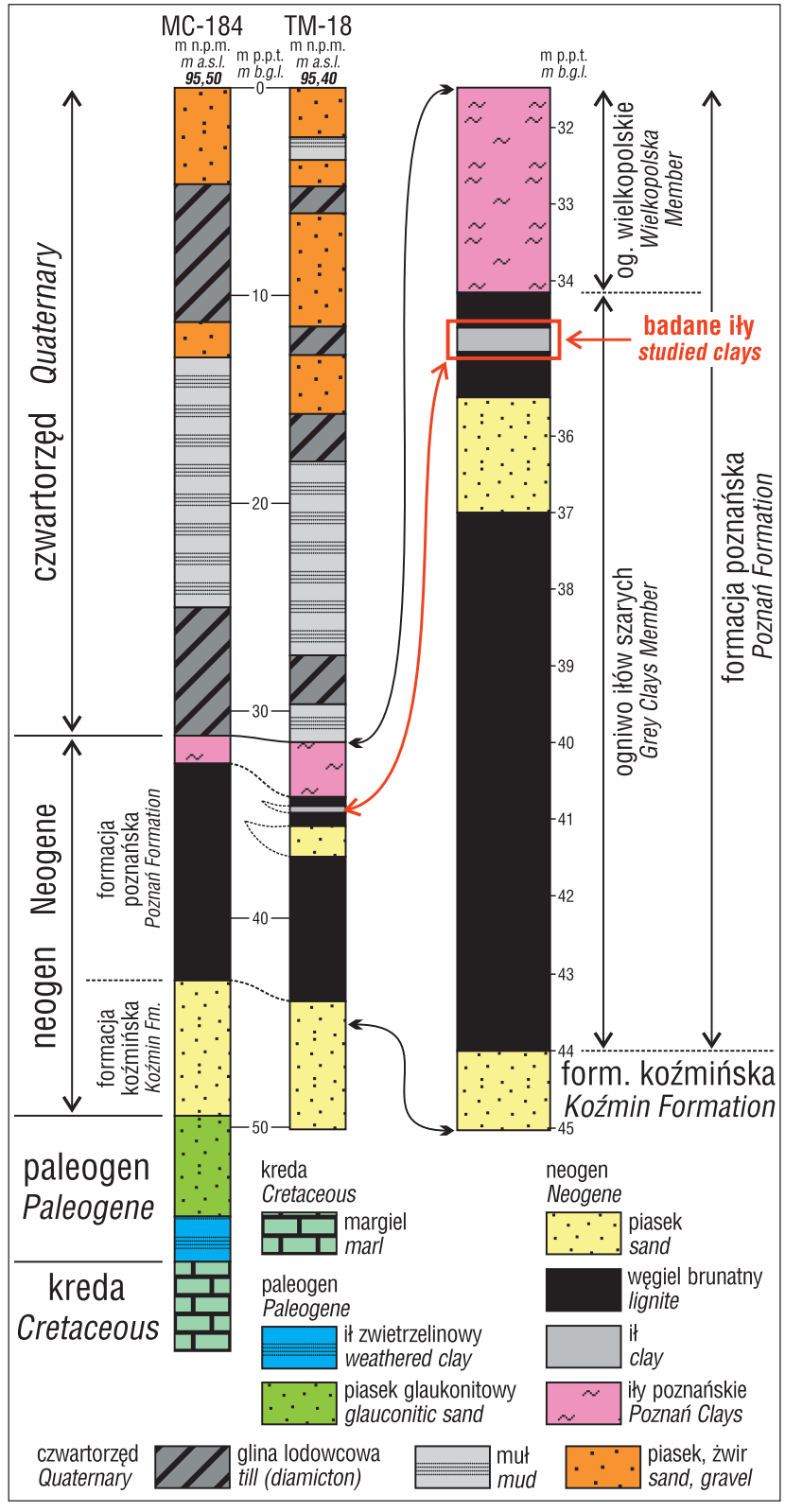

Ryc. 2. Litostratygrafia kenozoiku na obszarze złoża węgla brunatnego Tomisławice (wg Chomiak, 2020a, zmienione). Lokalizacja otworów MC-184 i TM-18 na rycinie 3

Fig. 2. Cenozoic lithostratigraphy in the area of the Tomisławice lignite deposit (after Chomiak, 2020a, modified). For location of boreholes MC-184 and TM-18 see Fig. 3

Neogen jest przykryty przez osady czwartorzędowe, których miąższość na obszarze badań waha się od 35 do $60 \mathrm{~m}$. Czwartorzęd często zalega wprost na stropie pokładu węgla brunatnego. Na obszarze badań osady czwartorzędowe są reprezentowane głównie przez gliny lodowcowe, żwiry i piaski o genezie fluwioglacjalnej oraz fluwioglacjalno-zastoiskowe muły (ryc. 2; Widera i in., 2017).

\section{METODYKA BADAŃ}

Badania terenowe i archiwalne, stanowiące podstawową część prezentowanych wyników, przeprowadzono w sezonie wiosenno-letnim 2019 r. Prace w odkrywce Tomisławice (ryc. 1) objęły kartowanie przewarstwienia iłów w ścianach węglowych, pobór próbek do badań laboratoryjnych i dokumentację fotograficzną. Ciągłą warstwę iłów udoku- 
mentowano łącznie na dystansie ok. $1 \mathrm{~km}$, gdzie w 11 miejscach pobrano z nich 35 próbek (ryc. 3). Miąższość badanych iłów wynosi od kilkunastu do $40 \mathrm{~cm}$ i występują one na wysokości do $3 \mathrm{~m}$ od stropu pokładu węglowego (ryc. 4, 5). W terenie określono makroskopowo facje iłów oraz litotypy niżej i wyżej zalegającego węgla brunatnego. W celu uproszczenia ich opisu użyto odpowiednio kodu litofacjalnego i litotypowego (tab. 1; ryc. 5; Widera, 2016b; Widera $i$ in., 2019).

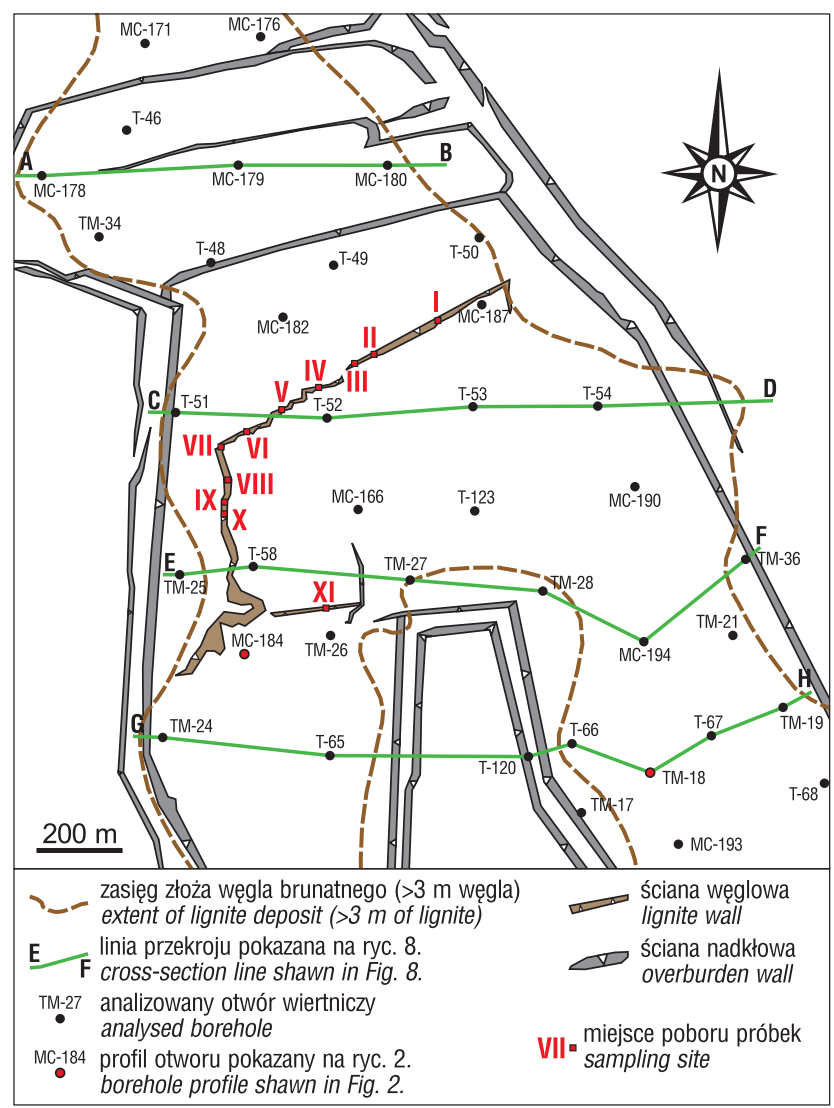

Ryc. 3. Mapa dokumentacyjna obszaru odkrywki Tomisławice (czerwiec 2019) z lokalizacją otworów wiertniczych, miejsc poboru próbek i przekrojów geologicznych analizowanych w tej pracy

Fig. 3. Documentation map of the Tomisławice opencast mine (June 2019) with location of boreholes, sampling sites and cross-sections analysed in this paper
W archiwum geologicznym PAK KWB Konin S.A. kwerendzie poddano 38 kart otworów wiertniczych z obszaru południowej i środkowej części złoża Tomisławice (por. ryc. 1 i 3 oraz tab. 2). W większości z nich stwierdzono badane iły międzywęglowe. Dlatego uzyskane dane otworowe posłużyły do wykonania: mapy miąższościowej iłów (ryc. 6), mapy strukturalnej spagu iłów (ryc. 7) oraz czterech równoleżnikowych, uproszczonych przekrojów geologicznych, uwzględniających przede wszystkim pokład węgla i występujące w nim iły, a także piaski (ryc. 3, 8).

Podczas prac laboratoryjnych 35 próbek (profile, miejsca I-XI na ryc. 3 i 9) poddano analizie uziarnienia metodą areometryczną. W ten sposób określono zawartość frakcji iłowej, pyłowej i piaskowej w analizowanych próbkach, a następnie osad nazwano zgodnie z klasyfikacją Sheparda (1954). W przypadku mieszaniny ww. frakcji w ilości co najmniej 20\% wag. każda (piasek-pył-ił wg Sheparda, 1954) użyto w tej pracy nazwy muł (ryc. 9). Dodatkowo trzy próbki iłów (profil, miejsce XI na ryc. 3 i 9) poddano badaniom na zawartość organiki. W tym celu próbki te, różniące się wyraźnie makroskopowo ze względu na zawartość detrytusu roślinnego, spalono w temp. $850^{\circ} \mathrm{C}$. Wyniki badań laboratoryjnych pozwoliły na bardziej precyzyjne określenie nazwy badanych osadów drobnoklastycznych (ryc. 9). Wreszcie wykonano odpowiednie proste obliczenia, mające na celu określenie wpływu przewarstwienia ilastego na popielność całego, obecnie eksploatowanego w odkrywce Tomisławice, pokładu węgla brunatnego.

\section{WYNIKI BADAŃ}

Poddane badaniom iły są widoczne makroskopowo w odkrywce Tomisławice, pomimo ich niewielkiej miąższości (25-40 cm) i niezbyt dużego kontrastu barwnego. Iły mają barwę jasnoszara, szara, po czarną (ryc. 5A) lub jasnobrązową (ryc. 5B), natomiast węgiel - ciemnobrązową i czarną (ryc. 4, 5). Udokumentowana rozciągłość ciagłej warstwy ilastej wynosi odpowiednio na ścianach o orientacji: E-W - ok. $200 \mathrm{~m}, \mathrm{~S}-\mathrm{N}$ - ok. $180 \mathrm{~m}$ i SW-NEok. $600 \mathrm{~m}$ (por. ryc. 3, 4, 6 i 7).

Opisywane iły nie są jednorodne teksturalnie. Oprócz wspomnianego już urozmaicenia barwnego, spowodowanego domieszką pyłu węglowego (detrytusu roślinnego), różnią się one też wielkością ziarna. Stosując podstawowe

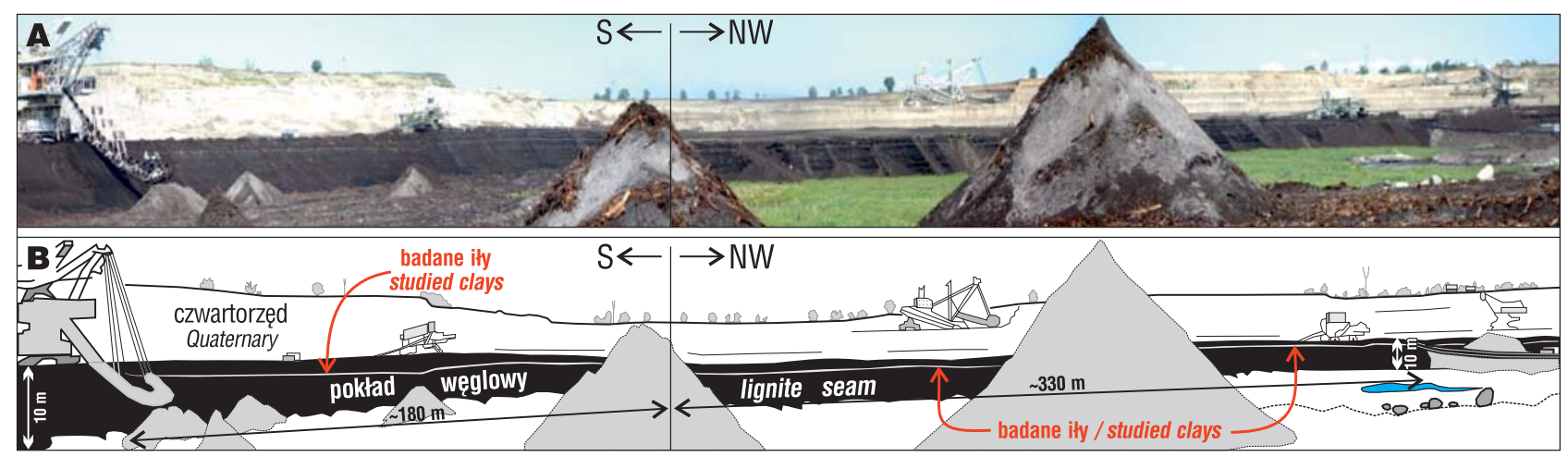

Ryc. 4. Panoramiczny widok osadów drobnoklastycznych w obrębie pierwszego środkowopolskiego pokładu węglowego (środkowy miocen) w odkrywce Tomisławice, czerwiec 2019. A - zestawienie fotografii; B - szkic przedstawiający szczegóły z ryciny 4A Fig. 4. Panoramic view of the fine-grained clastics within the first mid-Polish lignite seam in the Tomisławice opencast mine, June 2019. A- compilation of photographs; $\mathbf{B}$ - line drawing depicting details shown in Fig. 4A 

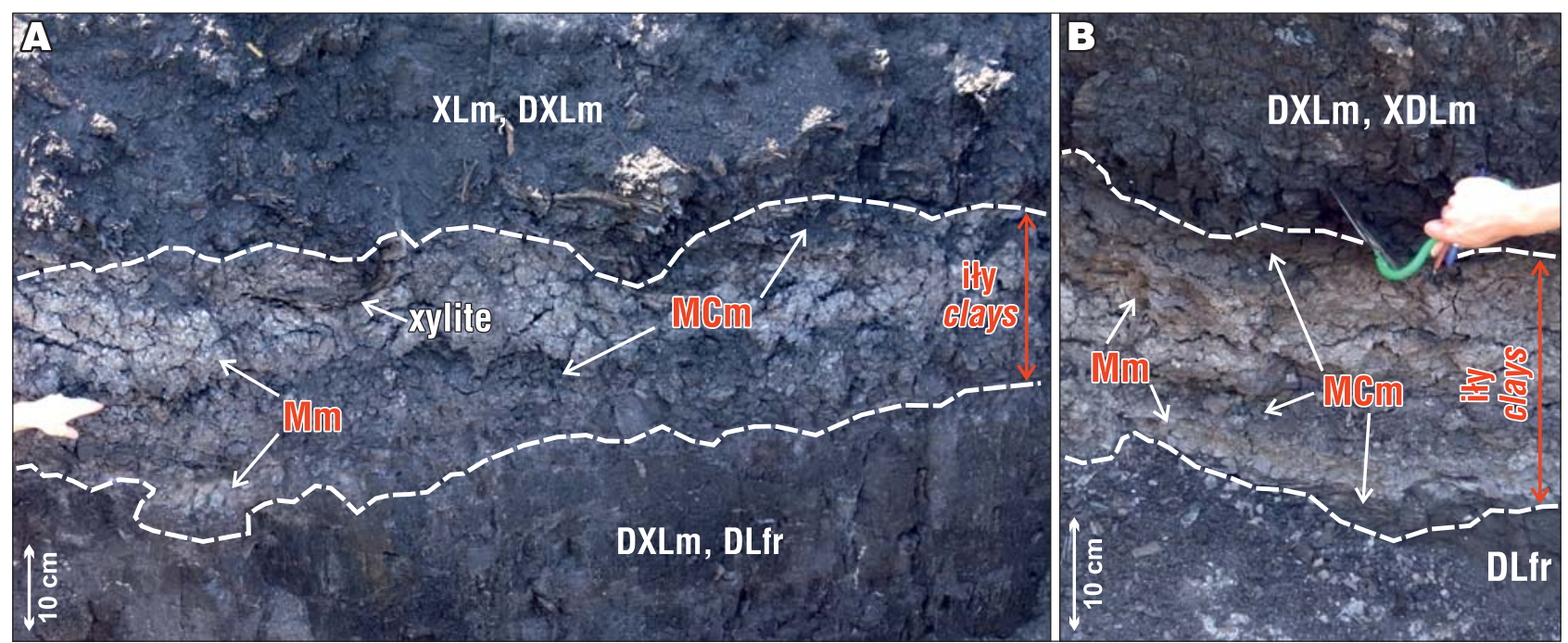

Ryc. 5. Widok badanych osadów drobnoziarnistych między warstwami węgla brunatnego w odkrywce Tomisławice, czerwiec 2019. Objaśnienia kodu facjalnego i litotypowego w tabeli 1

Fig. 5. View of the studied fine-grained sediments between lignite beds in the Tomisławice opencast mine, June 2019. For explanation of facies and lithotypes codes see Table 1

Tab. 1. Makroskopowa kodyfikacja drobnoziarnistych facji klastycznych (wg Widery i in., 2019) i litotypów węgla brunatnego (wg Widery, 2016b) wykorzystana w tej pracy

Table 1. Macroscopic codification of fine-grained clastic facies (after Widera et al., 2019) and lignite lithotypes (after Widera, 2016b) used in this paper

\begin{tabular}{|l|l|}
\hline \multicolumn{2}{|c|}{$\begin{array}{c}\text { Facje drobnoklastyczne } \\
\text { Fine-grained clastic facies }\end{array}$} \\
\hline Kod / Code & \multicolumn{1}{c|}{ Opis / Description } \\
\hline $\mathrm{Mm}$ & $\begin{array}{l}\text { muł masywny } \\
\text { mud with a massive structure }\end{array}$ \\
\hline $\mathrm{MCm}$ & $\begin{array}{l}\text { muł weglisty, masywny } \\
\text { coaly (carbonaceous) mud with a massive structure }\end{array}$ \\
\hline \multicolumn{2}{|c|}{$\begin{array}{c}\text { Litotypy wegla brunatnego } \\
\text { Lignite lithotypes }\end{array}$} \\
\hline Kod / Code & \multicolumn{1}{c|}{ Opis / Description } \\
\hline $\mathrm{DLfr}$ & $\begin{array}{l}\text { wegiel brunatny detrytowy, spekany } \\
\text { detrital lignite with a fractured structure }\end{array}$ \\
\hline $\mathrm{XDLm}$ & $\begin{array}{l}\text { wegiel brunatny ksylodetrytowy, masywny } \\
\text { xylodetritic lignite with a massive structure }\end{array}$ \\
\hline $\mathrm{DXLm}$ & $\begin{array}{l}\text { wegiel brunatny detroksylitowy, masywny } \\
\text { detroxylitic lignite with a massive structure }\end{array}$ \\
\hline $\mathrm{XLm}$ & $\begin{array}{l}\text { wegiel brunatny ksylitowy, masywny } \\
\text { xylitic lignite with a massive structure }\end{array}$ \\
\hline
\end{tabular}

metody terenowe (w tym organoleptyczne), w większości przypadków oprócz frakcji iłowej stwierdzono także frakcję pyłową oraz ziarna piasku. Dlatego makroskopowo badane osady nazwano mułami i mułami węglistymi o strukturze masywnej (ryc. 5; tab. 1). Warto dodać, że w omawianych iłach występują zarówno silnie spłaszczone fragmenty roślinności zielnej (najprawdopodobniej szuwarowej), o szerokości do $2 \mathrm{~cm}$ i grubości do $2-3 \mathrm{~mm}$, jak i uwęglone fragmenty roślinności drzewiastej o wielkości powyżej $1 \mathrm{~cm}$, tj. ksylity (ryc. 5A).

Zasięg badanych iłów nawiązuje w dużym przybliżeniu do rozprzestrzenienia objętej badaniami części złoża Tomisławice (ryc. 6,7). Iły zajmują powierzchnię $>1,5 \mathrm{~km}^{2}$, a ich rozciągłość w kierunku SSE-NNW, czyli zgodnym z orientacją złoża węgla brunatnego, wynosi ponad 2,2 km.
Natomiast w najszerszym miejscu, tj. w środkowej części badanego obszaru, omawiana warstwa iłów ma szerokość ok. 1,2 km (ryc. 6, 7).

Miąższość iłów w obrębie pokładu węglowego mieści się w przedziale $0-80 \mathrm{~cm}$ (ryc. 6; tab. 2). Ich najgrubsze wystąpienia są/były zlokalizowane w SE już wyeksploatowanej części złoża - $50 \mathrm{~cm}$ w otw. TM-21 i MC-190 - oraz w przeznaczonej do wydobycia NE części złoża $-80 \mathrm{~cm}$, otw. MC-180 (ryc. 6). Na terenie objętym badaniami, w dostępnym do bezpośrednich obserwacji w czasie prac terenowych, miąższość iłów wynosi 20-40 cm (por. ryc. 4-6).

Kształt warstwy iłów dobrze obrazuje mapa strukturalna ich powierzchni spagowej (strop jest współkształtny do spagu) oraz przekroje geologiczne (ryc. 7, 8). W obu przypadkach wyraźnie widać, że deniwelacje spagu i stropu analizowanej warstwy przekraczają $8 \mathrm{~m}$. W najniższym miejscu (otw. T-54) iły zalegają na rzędnych poniżej $56 \mathrm{~m}$ n.p.m., a na ich obrzeżach (np. otw. TM-34) wznoszą się na wysokość powyżej 64 m n.p.m. (ryc. 7). Warto zauważyć, że obniżenia warstwy iłów pokrywają się z miejscami ich największych miąższości. Z drugiej strony, ułożenie warstwy iłów nie zawsze jest współkształtne do spagu i/lub stropu pokładu węglowego, w którym występują (por. ryc. 6-8).

Według danych z dokumentacji geologicznej średnia zawartość popiołu w stanie suchym $\left(A^{d}\right)$ dla całego złoża Tomisławice wynosi 22,4\% (Kozula, 2001). W tym przypadku próbki były pobierane bruzdowo $\mathrm{z}$ rdzeni otworów wiertniczych, włączając przerosty mineralne do $30 \mathrm{~cm}$ grubości. Natomiast wyniki $A^{d}$ uzyskane dla 86 próbek pobieranych punktowo, bezpośrednio ze ścian węglowych w odkrywce wzdłuż całego pokładu, wynoszą średnio 15,9\% (Chomiak, 2020b). Należy zauważyć, że w ostatnim przypadku nie pobierano próbek z makroskopowo stwierdzonych przerostów mineralnych, w tym z badanych iłów.

\section{INTERPRETACJA WYNIKÓW I DYSKUSJA}

Wyniki badań laboratoryjnych pozwoliły sprecyzować nazwy osadów drobnoklastycznych, które w dokumentacjach geologicznych są zwane po prostu iłami (Kozula, 1999, 2001), a w terenie określono je jako muły i muły 
Tab. 2. Parametry pokładu węglowego oraz przewarstwień ilastych i piaszczystych w analizowanych otworach wiertniczych z obszaru złoża węgla brunatnego Tomisławice

Table 2. Parameters of the lignite seam, as well as clayey and sandy interbeddings, in the Tomisławice lignite deposit from the analysed boreholes

\begin{tabular}{|c|c|c|c|c|}
\hline $\begin{array}{l}\text { Numer otworu } \\
\text { Borehole No. }\end{array}$ & $\begin{array}{l}\text { Rzędna otworu [m n.p.m.] } \\
\text { Borehole elevation [m } \text { a.s.l.] }\end{array}$ & $\begin{array}{l}\text { Rzędna spągu i stropu } \\
\text { węgla brunatnego } \\
\text { [m n.p.m.] } \\
\text { Elevation of lignite base } \\
\text { and top [m a.s.l.] }\end{array}$ & $\begin{array}{c}\text { Rzędna spągu i stropu } \\
\text { ilów i/lub piasków } \\
\text { [m n.p.m.] } \\
\text { Elevation of clays } \\
\text { and/or sands* base and top } \\
\text { [m a.s.l.] }\end{array}$ & $\begin{array}{c}\text { Miąższość ilów } \\
\text { i/lub piasków [m] } \\
\text { Thickness of clays and/or } \\
\text { sands } *[\mathrm{~m}]\end{array}$ \\
\hline MC-171 & 96,25 & $51,05-61,95$ & $\begin{array}{l}60,05-60,45 \\
54,25-56,05^{*} \\
56,45-58,05^{*}\end{array}$ & $\begin{array}{l}0,4 \\
1,8^{*} \\
1,6^{*}\end{array}$ \\
\hline MC-176 & 100,61 & $47,11-59,11$ & - & 0,0 \\
\hline $\mathrm{T}-46$ & 95,89 & $52,89-61,89$ & $60,39-60,69$ & 0,3 \\
\hline MC-178 & 98,11 & $61,51-67,71$ & $\underset{-}{-} \underset{65,11-66,61^{*}}{ }$ & $\begin{array}{l}0,0 \\
1,5^{*}\end{array}$ \\
\hline MC-179 & 101,67 & $47,67-58,07$ & $\begin{array}{l}56,17-56,67 \\
48,67-49,67 * \\
\end{array}$ & $\begin{array}{l}0,5 \\
1,0^{*}\end{array}$ \\
\hline MC-180 & 99,23 & $47,23-57,43$ & $\begin{array}{l}56,23-57,03 \\
48,73-49,73^{*} \\
\end{array}$ & $\begin{array}{l}0,8 \\
1,0^{*}\end{array}$ \\
\hline TM-34 & 95,38 & $61,68-66,88$ & $63,98-64,38$ & 0,4 \\
\hline $\mathrm{T}-48$ & 95,87 & $58,57-65,07$ & $63,67-64,07$ & 0,4 \\
\hline $\mathrm{T}-49$ & 97,75 & $49,05-59,95$ & $57,65-58,05$ & 0,4 \\
\hline $\mathrm{T}-50$ & 99,12 & $52,12-57,12$ & - & 0,0 \\
\hline MC-182 & 97,33 & $54,33-63,33$ & $61,53-62,03$ & 0,5 \\
\hline MC-187 & 97,61 & $51,51-61,91$ & $\stackrel{-}{-}{ }_{55,81-58,41 *}$ & $\begin{array}{l}0,0 \\
2,6^{*}\end{array}$ \\
\hline $\mathrm{T}-51$ & 94,79 & $56,79-64,99$ & $62,99-63,39$ & 0,4 \\
\hline $\mathrm{T}-52$ & 96,05 & $\begin{array}{l}48,85-57,15 \\
51,85-59,25\end{array}$ & $\begin{array}{l}51,45-51,85 \\
57,15-57,55\end{array}$ & $\begin{array}{l}0,4 \\
0,4\end{array}$ \\
\hline $\mathrm{T}-53$ & 96,22 & $47,22-58,22$ & - & 0,0 \\
\hline $\mathrm{T}-54$ & 96,64 & $47,54-57,44$ & $55,04-55,44$ & 0,4 \\
\hline MC-166 & 96,11 & $48,31-59,11$ & $56,61-56,91$ & 0,3 \\
\hline $\mathrm{T}-123$ & 95,48 & $57,38-63,88$ & $62,18-62,48$ & 0,3 \\
\hline MC-190 & 95,25 & $49,55-60,75$ & $57,35-57,85$ & 0,5 \\
\hline TM-25 & 95,70 & $56,50-58,80$ & - & 0,0 \\
\hline $\mathrm{T}-58$ & 95,73 & $51,73-62,73$ & $60,23-60,43$ & 0,2 \\
\hline TM-27 & 95,65 & $62,85-65,85$ & $65,75->65,85$ & $>0,1$ \\
\hline TM-28 & 95,90 & $66,00-66,20$ & - & 0,0 \\
\hline TM-36 & 96,01 & $63,01-66,41$ & $\begin{array}{c}- \\
64,01-65,91 * \\
\end{array}$ & $\begin{array}{l}0,0 \\
1,9 *\end{array}$ \\
\hline MC-184 & 95,46 & $51,46-62,96$ & - & 0,0 \\
\hline TM-26 & 98,76 & $59,26-66,06$ & $63,26-63,56$ & 0,3 \\
\hline MC-194 & 95,84 & $50,74-61,34$ & - & 0,0 \\
\hline TM-21 & 95,71 & $55,21-62,31$ & $60,41-60,91$ & 0,5 \\
\hline TM-24 & 97,30 & $61,60-66,30$ & - & 0,0 \\
\hline $\mathrm{T}-65$ & 98,66 & $57,86-63,66$ & - & 0,0 \\
\hline $\mathrm{T}-120$ & 96,09 & $56,69-66,39$ & 57,09-66,09* & $\begin{array}{l}0,0 \\
9,0^{*}\end{array}$ \\
\hline T-66 & 95,50 & $54,30-62,50$ & $60,00-60,15$ & 0,15 \\
\hline $\mathrm{T}-67$ & 95,54 & $51,54-60,84$ & $59,09-59,24$ & 0,15 \\
\hline TM-19 & 96,08 & $57,08-63,58$ & - & 0,0 \\
\hline TM-18 & 95,37 & $51,37-61,27$ & $\begin{array}{l}60,47-60,77 \\
58,37-59,87^{*}\end{array}$ & $\begin{array}{l}0,3 \\
1,5^{*}\end{array}$ \\
\hline TM-17 & 96,08 & - & - & 0,0 \\
\hline MC-193 & 96,38 & $57,88-65,68$ & $61,98-65,48^{*}$ & $\begin{array}{l}0,0 \\
3,5^{*}\end{array}$ \\
\hline $\mathrm{T}-68$ & 95,58 & $51,58-61,68$ & - & 0,0 \\
\hline
\end{tabular}

* Przewarstwienia piaszczyste (osady stożków krewasowych) w pokładzie węglowym.

*Sandy interbeddings (crevasse-splay sediments) within the lignite seam. 


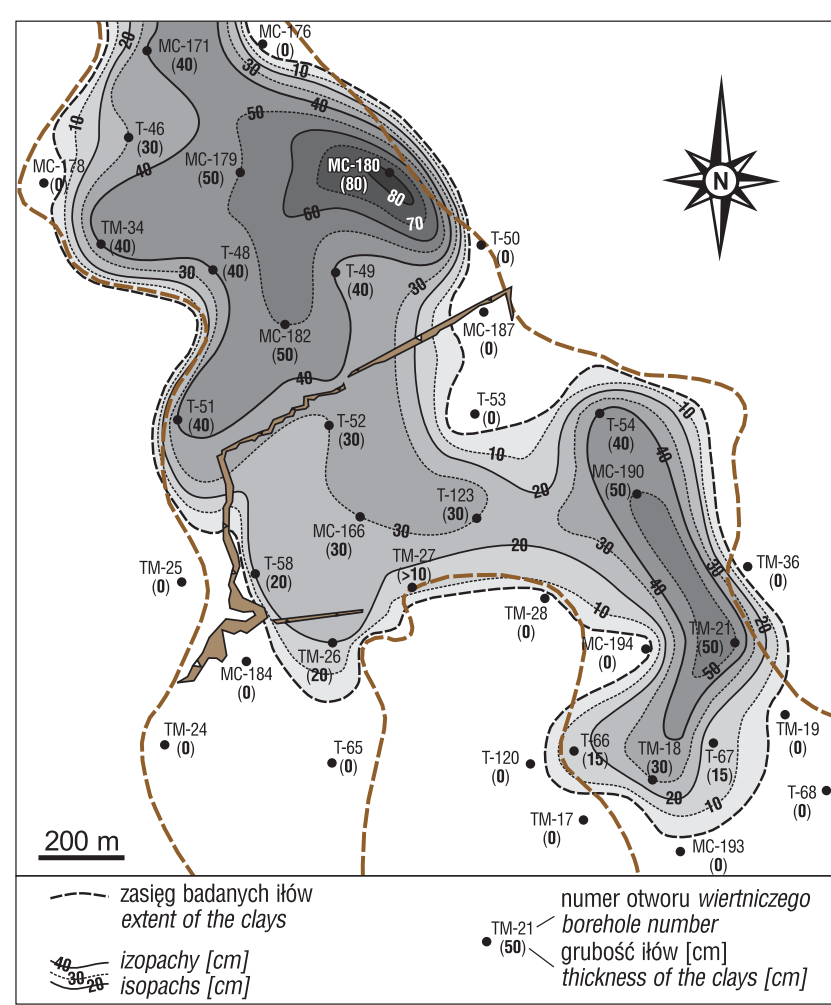

Ryc. 6. Mapa miąższości warstwy iłu w pokładzie ze złoża węgla brunatnego Tomisławice

Fig. 6. Thickness map of the clayey layer within the lignite seam from the Tomisławice lignite deposit

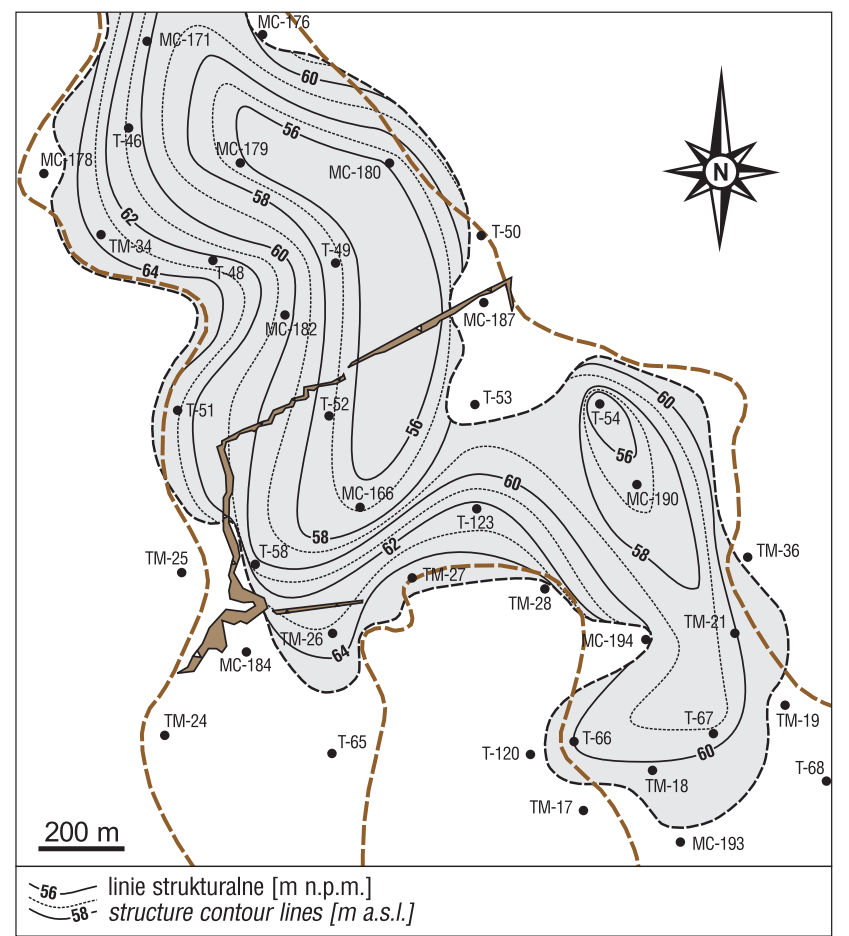

Ryc. 7. Mapa strukturalna spagu środkowomioceńskiej warstwy ilastej przedstawionej na rycinie 6

Fig. 7. Structural map of the base of the clayey layer show in Fig. 6

węgliste (por. ryc. 5 i tab. 1). Okazało się, że podane wyżej nazwy są tylko częściowo poprawne dla badanych próbek (ryc. 9). Tylko jedna z przebadanych próbek (pr. I2) może być nazwana iłem, gdyż zawiera $>75 \%$ wag. frakcji iłowej wg kryterium Sheparda (1954). Z drugiej strony, więk- szość próbek nie reprezentuje mułów, a jeśli zostałaby zastosowana klasyfikacja Lundegarda i Samuelsa (1980) (33-66\% wag. frakcji pyłowej i $<50 \%$ wag. frakcji piaskowej), to żadnej próbki nie należałoby nazwać mułem. Innymi słowy, największa liczba próbek reprezentuje ił pylasty 21 próbek, a tylko 3 próbki to ił piaszczysty. Natomiast 10 próbek, obejmujących wszystkie frakcje (piaskowa, pyłową, iłową) w ilości $>20 \%$ wag. (Shepard, 1954), spełnia kryteria mułu i tak są w tej pracy opisane. Najwięcej najgrubszych ziaren, tj. frakcji piaskowej i pyłowej, występuje w profilach VIII i IX, zaś najdrobniejsza frakcja jest w profilu I. Wskazuje to na generalny kierunek transportu materiału drobnookruchowego z zachodu na wschód (por. ryc. 3 i 9).

Pionowa zmienność uziarnienia jest zauważalna w większości analizowanych profili. Obecność w iłach warstw (soczew) wzbogaconych w detrytus roślinny do 34\% wag. (ryc. 5, 9) dowodzi zmieniających się warunków depozycji, w tym kilkuetapowej dostawy cząstek mineralnych i organicznych do zbiornika sedymentacyjnego. Osad drobnoklastyczny pochodził zapewne z koryt rzecznych opływających torfowisko (Bos i in., 2009, 2012; Widera, 2016a). Z kolei źródłem detrytusu roślinnego, tj. pyłu węglowego i fragmentów łodyg roślinności zielnej, była prawdopodobnie roślinność porastająca strefę przybrzeżną (do ok. $2 \mathrm{~m}$ ) zbiornika wodnego istniejącego na powierzchni torfowiska (np. Horne i in., McCabe, 1984; 1978; Diessel i in., 2000). W głębszej (>2 m) części płytkiego jeziora położonego w strefie pozakorytowej środkowomioceńskiej rzeki przeważała, a nawet dominowała sedymentacja klastyczna z zawiesiny (np. Lv i in., 2016; Widera, 2016a; Erkoyun i in., 2017; Matys Grygar i in., 2017). Natomiast ksylity w badanych iłach mają dwojakie pochodzenie. Część z nich była redeponowana spoza zbiornika sedymentacyjnego, stanowiąc fragmenty roślinności krzewiastej i drzewiastej, która porastała wyniesienia (powyżej poziomu wód gruntowych) na środkowomioceńskim torfowisku i jego otoczeniu (Kwiecińska, Wagner, 1997; Markič, Sachsenhofer, 1997; Widera, 2016b). Natomiast pozostałe ksylity to uwęglone fragmenty korzeni roślinności krzewiastej i drzewiastej, z której m.in. powstała górna ława węglowa (ryc. 5A).

Rozprzestrzenienie badanych iłów w złożu Tomisławice jest największe spośród wszystkich złóż eksploatowanych przez PAK KWB Konin S.A. Dotyczy to także przewarstwień piaszczystych reprezentujących stożki krewasowe, odsłoniętych do bezpośrednich obserwacji w odkrywkach Tomisławice (Widera, 2016a; Widera i in., 2017; Chomiak, 2020a) i Jóźwin IIB (Chomiak i in., 2019a, b; van Loon, 2019). Przewarstwienia te występują w brzeżnych lub spągowych partiach pokładu węglowego, co wpływa na zmniejszenie zasobów, ale nie utrudnia eksploatacji poprzez odpowiednie okonturowanie złoża. Natomiast w przypadku badanych iłów międzywęglowych ze złoża Tomisławice, to zalegają one na przeważającym jego obszarze, w tym w jego strefie osiowej (ryc. 6, 7). Ponadto obecność warstwy iłów o grubości dochodzącej do $80 \mathrm{~cm}$ powoduje nie tylko problemy geologiczno-górnicze (m.in. podwyższa stosunek nadkładu do węgla), ale przede wszystkim niekorzystnie wpływa na parametry chemiczno-technologiczne węgla głównie na zawartość popiołu. Niestety aktualnie, poza wyjątkowymi sytuacjami, w odkrywce Tomisławice nie jest prowadzona, ze względów technologicznych i finanso- 


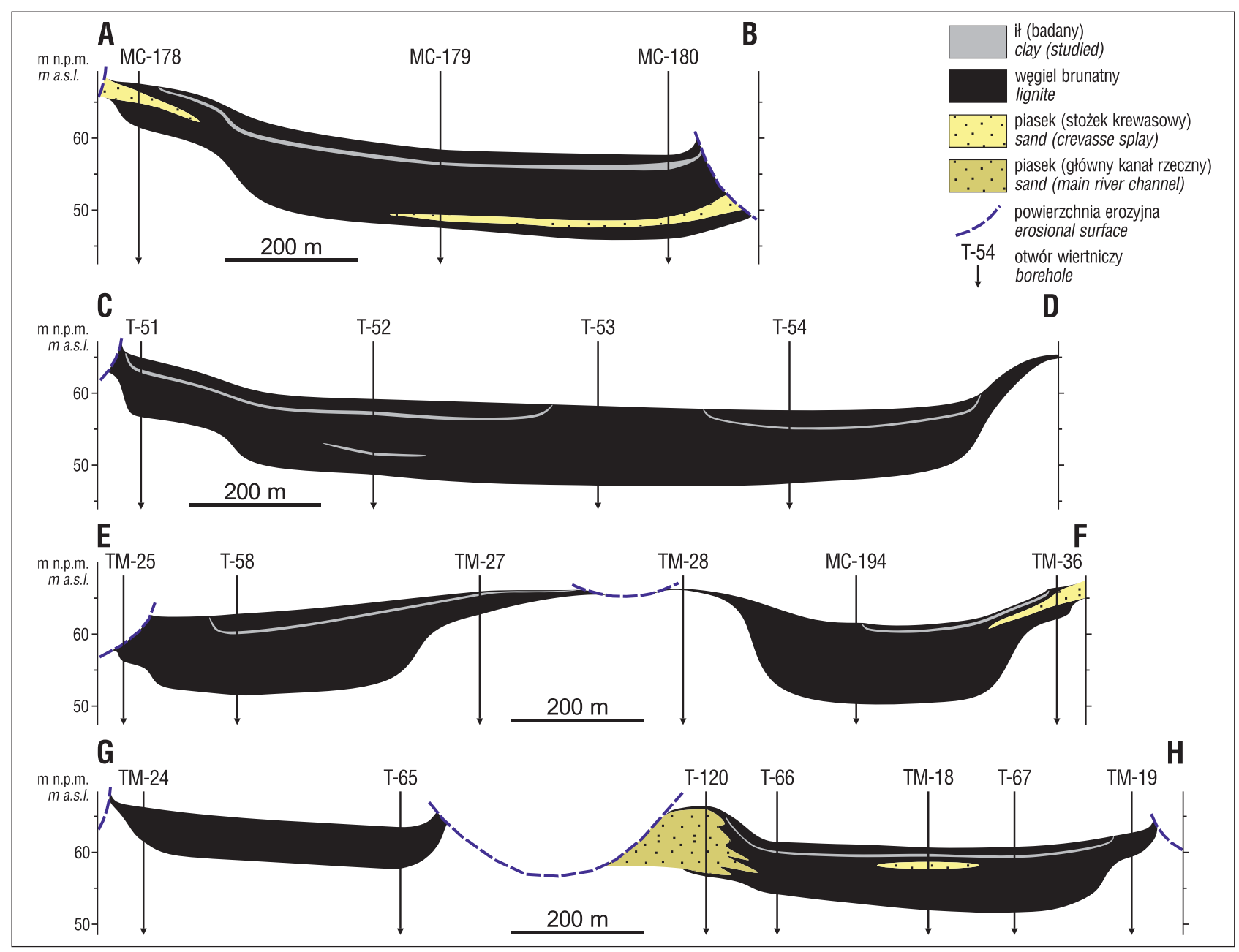

Ryc. 8. Uproszczone przekroje geologiczne ukazujące architekturę przewarstwień klastycznych (iłów i piasków) w obrębie pierwszego środkowopolskiego pokładu węglowego (środkowy miocen) w złożu Tomisławice. Lokalizacja linii przekrojowych na ryc. 3

Fig. 8. Simplified cross-sections depicting an architecture of the clastic interbeddings (clays and sands) within the first mid-Polish lignite seam in the Tomisławice deposit. For location of the cross-section lines see Fig. 3

wych, selektywna eksploatacji dolnej i górnej ławy węglowej. W ostatnim przypadku nie byłoby spełnione kryterium bilansowe (>3 m miąższości węgla), gdyż górna ława węglowa w przeanalizowanych otworach ma grubość od 0,4 m w otw. MC-180 do 2,9 m w otw. MC-190 (tab. 2).

Ułożenie warstwy iłów na obszarze ich występowania jest w przybliżeniu równoległe zarówno do spagu, jak i stropu pokładu węglowego. Jednakże w brzeżnych partiach są one często silnie poddarte, dochodząc do stropu węgla, co zaobserwowano $\mathrm{w}$ terenie (ryc. 10) i zinterpretowano na przekrojach (ryc. 8). W niektórych przypadkach, gdzie architektura warstwy iłów nawiązuje do kształtu spagu węgla (otoczenie otworów: MC-178, T-51, TM-27, TM-36, T-66 i TM-19), przyczyn takiego ułożenia iłów można dopatrywać się w tektonice postdepozycyjnej. Natomiast pozostałe przypadki (otoczenie otworów: T-53, T-58 i MC-194) skłaniają do łączenia poddarcia warstwy iłów z nierównomierną, postdepozycyjną kompakcją dolnej ławy węglowej (ryc. 8,10$)$. W ten sposób, pod ciężarem względnie grubej (do $80 \mathrm{~cm}$ ) warstwy badanych osadów drobnoklastycznych, postępująca kompakcja doprowadziła do utworzenia przestrzeni akomodacyjnej dla młodszych warstw torfu. W efekcie powstała górna ława węglowa, której obserwowana i nawiercona miąższość nie przekracza $3 \mathrm{~m}$ (por. ryc. 4, 10 i tab. 2). Niemniej jednak, ze względu na skutki plejstoceńskich procesów niszczących (erozja i egza- racja) trudno jest wyznaczyć pierwotny zasięg i miąższość wspomnianej górnej ławy węglowej. Dlatego nie można też określić rozmiarów deformacji warstwy iłów wywołanych zarówno przez subsydencję tektoniczną, jak i kompakcyjną (Widera, 2007).

Badana warstwa iłów ma zróżnicowany wpływ na popielność całego pokładu, w zależności od stosunku miąższości iłu do węgla. Dla uproszczenia obliczeń i interpretacji wyników przyjęto gęstość objętościową dla węgla brunatnego $1,2 \mathrm{Mg} / \mathrm{m}^{3}$, dla iłów $2,0 \mathrm{Mg} / \mathrm{m}^{3}$ oraz średnią popielność $A^{d}=17,2 \%$ (Chomiak, 2020b). W przypadku otw. T-67 (9,15 m węgla i 0,15 m iłu; ryc. 6; tab. 2) wydobycie tej cienkiej warstwy iłu razem z węglem zwiększa popielność całego pokładu tylko o ok. 2,4\%. Inaczej sytuacja wygląda w otw. MC-180, jeśli uwzględniony zostanie pokład powyżej warstwy piasków interpretowanych jako osady stożka krewasowego (ryc. 8). W tym przypadku łączna grubość pokładu wynosi 7,7 m, gdzie 6,9 m stanowi węgiel, a $0,8 \mathrm{~m}$ ił - jest to największa miąższość warstwy iłu na całym badanym obszarze (por. ryc. 6 i 8). W efekcie wydobycie węgla razem $\mathrm{z}$ przewarstwieniem ilastym powoduje wzrost popielności do ok. 32,7\%. Innymi słowy, niespełna $1 \mathrm{~m}$ iłu zawiera więcej materii mineralnej (popiołu) niż blisko $7 \mathrm{~m}$ węgla brunatnego. Powyższe wyniki prostych obliczeń jasno pokazują, że nieselektywna eksploatacja węgla, tj. razem z warstwą iłów, w skrajnych 


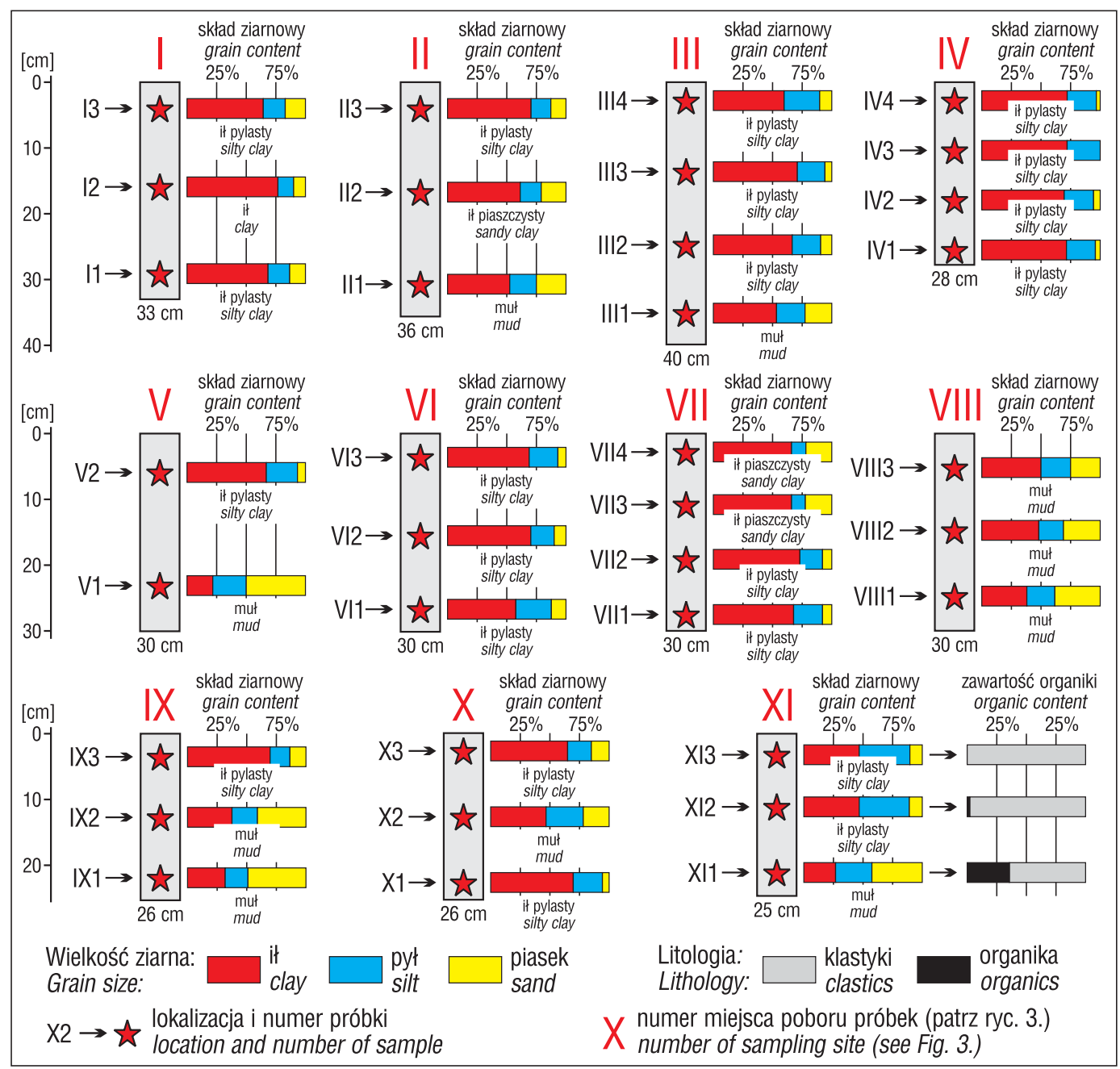

Ryc. 9. Graficzne przedstawienie wyników badań laboratoryjnych iłów obejmujących głównie wielkość ziarna i dodatkowo zawartość organiki. Lokalizacja miejsc poboru analizowanych próbek na rycinie 3

Fig. 9. Graphic representation of the results of laboratory tests of clays, covering mainly grain size and additionally organic content. For location of the sampling sites see Fig. 3
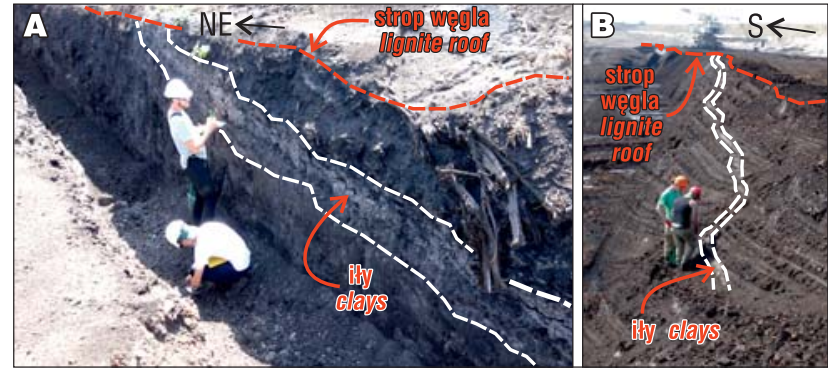

Ryc. 10. Poddarcie warstwy iłów w brzeżnej strefie ich występowania: A - o ok. $1 \mathrm{~m}$ na dystansie poniżej $10 \mathrm{~m}, \mathbf{B}$ - o blisko $3 \mathrm{~m}$ na dystansie ok. $50 \mathrm{~m}$

Fig. 10. Upturned layer of clays in the marginal zone of their occurrence: A-by about $1 \mathrm{~m}$ at a distance of less than $10 \mathrm{~m}, \mathbf{B}$ - by almost $3 \mathrm{~m}$ at a distance of about $50 \mathrm{~m}$

przypadkach skutkuje wzrostem popielności węgla dostarczanego do elektrowni nawet o ok. 15,5\%. Oczywiście uśredniona wartość jest mniejsza i najprawdopodobniej zbliżona do różnicy między wartościami uzyskanymi dla próbek węgla pobieranych bruzdowo (z przerostami mineralnymi) $-A^{d}=22,4 \%$ (Kozula, 2001), a wynikami uzyskanymi dla selektywnie pobieranych próbek węgla (bez przerostów mineralnych) $-A^{d}=17,2 \%$ (Chomiak, 2020b).

\section{WNIOSKI}

Na obszarze złoża węgla brunatnego Tomisławice udokumentowano warstwę iłu w obrębie aktualnie eksploatowanego pierwszego środkowopolskiego pokładu węglowego. Przewarstwienie osadów drobnoklastycznych ma względnie duże rozprzestrzenienie i miąższość, co utrudnia wydobycie węgla i negatywnie wpływa na jego wartość opałową.

Ich architektura na przeważającym obszarze nawiązuje do ukształtowania stropu i spagu pokładu węglowego. Sa jednak przypadki, dobrze widoczne $\mathrm{w}$ terenie i na przekrojach geologicznych, gdzie takiej zależności brak. Należy dodać, że stropowe warstwy pokładu węgla są częściowo usunięte przez plejstoceńską erozję i egzarację. Dlatego trudno jest określić wpływ tektoniki i kompakcji na ukształtowanie warstwy międzywęglowych osadów klastycznych.

Poddane badaniom osady międzywęglowe reprezentują głównie ił pylasty, a także muł, ił piaszczysty i ił. Większość przebadanych próbek nie zawiera substancji organicznej lub zawiera jej śladowe ilości. Niemniej jednak w pojedynczych próbkach stwierdzono nawet do $34 \%$ wag. organiki w postaci pyłu węglowego i/lub ksylitów, będących uwęglonymi fragmentami zarówno roślinności zielnej, jak 
i krzaczasto-drzewiastej. Pionowy i poziomy rozkład uziarnienia wzdłuż ścian eksploatacyjnych w odkrywce Tomisławice wskazuje na więcej niż jeden cykl sedymentacyjny, a także na zachodni kierunek dostawy materiału klastycznego do basenu sedymentacyjnego.

Biorąc pod uwagę rozprzestrzenienie, architekturę stratygraficzną oraz cechy teksturalno-strukturalne badanych iłów, można jednoznacznie stwierdzić, że powstały one w zbiorniku jeziornym, który występował na powierzchni środkowomioceńskiego torfowiska. Jezioro to było zasilane przez wody powodziowe pobliskiej rzeki, która pozostawiła w sąsiedztwie osady piaszczyste kilku stożków krewasowych, udokumentowanych w brzeżnych częściach złoża Tomisławice.

W praktyce górniczej węgiel brunatny w odkrywce Tomisławice jest eksploatowany razem $\mathrm{z}$ analizowanym przerostem ilastym. Jak wykazano w tej pracy, popielność węgla jest średnio o kilka, a w skrajnych przypadkach nawet o kilkanaście procent wyższa niż byłaby w sytuacji, gdyby węgiel był wydobywany selektywnie, tj. bez warstwy iłów. Niemniej jednak obecne uwarunkowania technologiczne, a przede wszystkim finansowe sprawiają, że takie działania są podejmowane tylko lokalnie.

Autorzy serdecznie dziękują pracownikom Działu Geologicznego PAK KWB Konin S.A. za pomoc w czasie prac terenowych i archiwalnych. Ponadto słowa wdzięczności kierujemy do prof. Z. Kasztelewicza i dr. J.R. Kasińskiego za bardzo pozytywne recenzje oraz do prof. W. Treli za pomoc edytorską. Prezentowana praca została sfinansowana z funduszy Narodowego Centrum Nauki, grant nr 2017/27/B/ST10/00001.

\section{LITERATURA}

BOS I.J., FEIKEN H., BUNNIK F., SCHOKKER J. 2009 - Influence of organics and clastic lake fills on distributary channel processes in the distal Rhine-Meuse delta (The Netherlands). Palaeogeograph., Palaeoclimat., Palaeoecol., 284: 355-374.

BOS I.J., BUSSCHERS F.S., HOEK W.Z. 2012 - Organic-facies determination: a key for understanding facies distribution in the basal peat layer of the Holocene Rhine-Meuse delta, The Netherlands. Sedimentology, 59: 679-703.

CHOMIAK L. 2020a - Crevasse splays within a lignite seam at the Tomisławice opencast mine near Konin, central Poland: architecture, sedimentology and depositional model. Geologos, 26: 25-37.

CHOMIAK L. 2020b - Variation of lignite ash in vertical and horizonta sections of mining walls in the Konin Lignite Mine, central Poland. Geol., Geophys., Environ., 46: 17-28.

CHOMIAK L., WACHOCKI R., MACIASZEK P., WIDERA M. ZIELINSKI T. 2019a - Seismically deformed the crevasse-splay microdelta deposits - an example from Mid-Miocene of Poland. Geol. Quart., 63: 162-177.

CHOMIAK L., WACHOCKI R., MACIASZEK P., WIDERA M., ZIELIŃSKI T. 2019b - Seismically deformed the crevasse-splay microdelta deposits - an example from Mid-Miocene of Poland - reply. Geol Quart., 63: 429-433.

DADLEZ R., MAREK S., POKORSKI J. (red.) 2000 - Mapa Geologiczna Polski bez kenozoiku w skali 1 : 1000 000. Państw. Inst. Geol., Warszawa DIESSEL C., BOYD R., WADSWORTH J., LECKIE D., CHALMERS G. 2000 - On balanced and unbalanced accommodation/peat accumulations ratios in the Cretaceous coals from Gates Formation, Western Canada, and their sequence-stratigraphic significance. Inter. J. Coal Geol., 43: $143-186$.

DOKTOR M. 2007 - Conditions of accumulation and sedimentary architecture of the upper Westphalian Cracow Sandstone Series (Upper Silesia Coal Basin, Poland). Ann. Soc. Geol. Pol., 77: 219-268.

ERKOYUN H., KADIR S., KÜLAH T., HUGGETT J. 2017 - Mineralogy, geochemistry and genesis of clays interlayered coal seams succession in the Neogene lacustrine Seyitömer coal deposit, Kütahya, western Turkey. Inter. J. Coal Geol., 172: 112-133.

GRADZIŃSKI R., BARYŁA J., DANOWSKI W., DOKTOR M., GMUR D., GRADZIŃSKI M., KĘDZIOR A., PASZKOWSKI M., SOJA R.,
ZIELIŃSKI T., ŻUREK S. 2000 - Anastomosing system of the upper Narew river, NE Poland. Ann. Soc. Geol. Pol., 70: 219-229.

HORNE J.C., FERM J.C., CARUCCIO F.T., BAGANZ B.P. 1978 Depositional models in Coal Exploration and Mine Planning in Appalachian Region. Am. Ass. Petrol. Geol. Bull., 62: 2379-2411.

KASIŃSKI J.R. 1986 - Sedimentary models of small lignite deposits: examples from the Polish Neogene. Prz. Geol., 34: 189-197.

KASIŃSKI J.R. 1989 - Lacustrine sedimentary sequences in the Polish Miocene lignite-bearing basins - Facies distribution and sedimentary development. Palaeogeograph., Palaeoclimat., Palaeoecol., 70: 287-304. KASZTELEWICZ Z., PTAK M., SIKORA M. 2018 - Węgiel brunatny optymalnym surowcem energetycznym dla Polski. Zesz. Nauk. IGSMiE PAN, 106: 61-84.

KOZULA R. 1999 - Dokumentacja geologiczna złoża węgla brunatnego „Tomisławice” w kategorii C1 i C2, Część I - tekst. Przed. Geol. PROXIMA, Wrocław.

KOZULA R. 2001 - Dokumentacja geologiczna złoża węgla brunatnego „Tomisławice” w kategorii B i C1 w Tomisławicach, Część I - tekst. Przed. Geol. PROXIMA, Wrocław.

KWIECIŃSKA B., WAGNER M. 1997 - Typizacja cech jakościowych wegla brunatnego z krajowych złóż według kryteriów petrograficznych i chemiczno-technologicznych dla celów dokumentacji geologicznej złóż oraz obsługi kopalń. Wyd. Centrum PPGSMiE PAN, Kraków: 1-87. LUNDEGARD P.D., SAMUELS N.D. 1980 - Field classification of fine-grained sedimentary rocks. J. Sediment. Petrol., 50: 781-786.

LV D., FENG T., LI Z., LIU H., YONG P., YANG Q. 2016 - Sedimentary characteristics of clay deposits associated with coal beds and their geological implications for the Eastern Yanzhou Caolfield, Nort China. Indian J. Geo-Marine Sci., 45: 5-15.

MATYS GRYGAR T., MACH K., HOŠEK M., SCHNABL P. MARTINEZ M., KOUBOVÁ M. 2017 - Early stages of clastic deposition in the Most Basin (Ohře Rift, Czech Republic, Early Miocene): timing and possible controls. Bull. Geosci., 92: 337-355.

MCCABE P.J. 1984 - Depositional models of coal and coal-bearing strata. [W:] Rahmani R.A., Flores R.M. (red.), Sedimentology of coal and coal-bearing sequences. Int. Ass. Sediment., Spec. Publ., 7: 13-42.

MOROZOVA G.S., SMITH N.D. 2000 - Holocene avulsion styles and sedimentation patterns of the Saskatchewan River, Cumberland Marshes, Canada. Sediment. Geol., 130: 81-105.

MARKIČ M., SACHSENHOFER R.F. 1997 - Petrographic composition and depositional environments of the Pliocene Velenje lignite seam (Slovenia). Int. J. Coal Geol., 33: 229-254.

PIWOCKI M., ZIEMBIŃSKA-TWORZYDŁO M. 1997 - Neogene of the Polish Lowlands - lithostratigraphy and pollen-spore zones. Geol. Quart., 41: 21-40.

SHEPARD F.P. 1954 - Nomenclature based on sand-silt-clay ratios. J. Sediment. Res., 24: 151-158.

MASTALERZ M. 1992 - Petrografia i warunki depozycji pokładów węgla formacji wałbrzyskiej w niecce śródsudeckiej (SW Polska). Geol. Sudet., 26: 1-82.

MAZUREK S., TYMIŃSKI M. 2019 - Węgle brunatne. [W:] Szuflicki M., Malon A., Tymiński M. (red.), Bilans zasobów złóż kopalin w Polsce wg stanu na 31 XII 2018 r. Państw. Inst. Geol., Warszawa: 34-39.

VAN LOON A.J. 2019 - Seismically-induced soft-sediment deformation in crevasse-splay microdelta deposits (Middle Miocene, central Poland): comment. Geol. Quart., 63: 424-428.

WIDERA M. 2007 - Litostratygrafia i paleotektonika kenozoiku podplejstoceńskiego Wielkopolski. Geologia, 18, Wyd. Nauk. UAM, Poznań: $1-224$.

WIDERA M. 2016a - Depositional environments of overbank sedimentation in the lignite-bearing Grey Clays Member: New evidence from Middle Miocene deposits of central Poland. Sediment. Geol., 335: 150-165. WIDERA M. 2016b - An overview of lithotype associations forming the exploited lignite seams in Poland. Geologos, 22: 213-225.

WIDERA M. 2017 - Sedimentary breccia formed atop a Miocene crevasse-splay succession in central Poland. Sediment. Geol., 360: 96-104.

WIDERA M., CHOMIAK L., GRADECKI D., WACHOCKI R. 2017 -

Osady glifu krewasowego z miocenu Polski środkowej w okolicach Konina. Prz. Geol., 65: 251-258.

WIDERA M., CHOMIAK L., ZIELIŃSKI T. 2019 - Sedimentary facies, processes and paleochannel pattern of an anastomosing river system: an example from the Upper Neogene of Central Poland. J. Sediment. Res., 89: 487-507.

WIDERA M., KITA A. 2017 - Paleogene marginal marine sedimentation in central-western Poland. Geol. Quart., 51: 79-90.

ŻELAŹNIEWICZ A. ALEKSANDROWSKI P., BUŁA Z., KARNKOWSKI P.H., KONON A., ŚLĄCZKA A., ŻABA J., ŻYTKO K. 2011 Regionalizacja tektoniczna Polski. Komitet Nauk Geologicznych PAN, Wrocław: 1-60.

Praca wpłynęła do redakcji 20.11.2019 r.

Akceptowano do druku 12.03.2020 r. 